\title{
High testosterone levels in prostate tissue obtained by needle biopsy correlate with poor-prognosis factors in prostate cancer patients
}

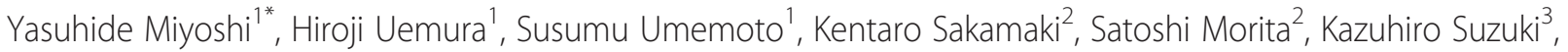 \\ Yasuhiro Shibata ${ }^{3}$, Naoya Masumori ${ }^{4}$, Tomohiko Ichikawa ${ }^{5}$, Atsushi Mizokami ${ }^{6}$, Yoshiki Sugimura ${ }^{7}$, \\ Norio Nonomura ${ }^{8}$, Hideki Sakai ${ }^{9}$, Seijiro Honma ${ }^{10}$, Masaoki Harada ${ }^{11}$ and Yoshinobu Kubota ${ }^{1}$
}

\begin{abstract}
Background: There is currently no consensus on the correlations between androgen concentrations in prostate tissue and blood and stage and pathological grade of prostate cancer. In this study, we used a newly-developed ultra-sensitive liquid-chromatography tandem mass spectrometry method to measure testosterone (T) and dihydrotestosterone (DHT) concentrations in blood and needle biopsy prostate specimens from patients with prostate cancer.

Methods: We analyzed androgen levels in 196 men diagnosed with prostate cancer. All patients had undergone systematic needle biopsy, and an additional needle biopsy from the peripheral zone was conducted for the simultaneous determination of T and DHT. We analyzed the relationships between T and DHT levels in tissue and blood and Gleason score, clinical stage, and percentage of positive biopsy cores, using multivariate analysis.

Results: The median T and DHT levels in blood were $3551.0 \mathrm{pg} / \mathrm{mL}$ and $330.5 \mathrm{pg} / \mathrm{mL}$, respectively. There was a strong correlation between serum T and DHT. The median T and DHT levels in prostate tissue were $0.5667 \mathrm{pg} / \mathrm{mg}$ and $7.0625 \mathrm{pg} / \mathrm{mg}$, respectively. In multivariate analysis, serum prostate-specific antigen and tissue T levels were significantly associated with poor prognosis; high T levels in prostate tissue were significantly related to high Gleason score $(p=0.041)$, advanced clinical stage $(p=0.002)$, and a high percentage of positive biopsy cores $(p=0.001)$.

Conclusions: The results of this study indicate that high $T$ levels in prostate tissue are related to high Gleason score, advanced clinical stage, and a high percentage of positive biopsy cores in patients with prostate cancer. T level in needle biopsy specimens may therefore be a useful prognostic factor in prostate cancer patients.
\end{abstract}

Keywords: Prostate cancer, Androgen, Testosterone, Dihydrotestosterone

\section{Background}

Prostate cancer is the most common internal cancer and the second most frequent cause of cancer-related deaths among men in the United States. Although the incidence of prostate cancer in Japan is lower than in the United States, it has been gradually increasing in recent years. The etiology of prostate cancer is unclear, but it is thought to be multifactorial, with genetic, dietary, and environmental causes. Although prostate cancer initially responds to androgen ablation therapy, most patients

\footnotetext{
* Correspondence: miyoyasu@med.yokohama-cu.ac.jp

'Department of Urology, Yokohama City University Graduate School of Medicine, Yokohama, Japan

Full list of author information is available at the end of the article
}

ultimately become hormone-refractory and show treatment failure.

The ability to predict prostate tumor behavior is important, because more intensive treatment is necessary to prevent the development of castration-resistant prostate cancer (CRPC). Pathological grade and clinical stage can strongly predict tumor aggressiveness, but no useful molecular markers have yet been identified. Several previous studies have reported blood and prostate tissue levels of testosterone (T) and dihydrotestosterone (DHT) in patients with prostate cancer, but these studies have involved small sample sizes, and several have measured the levels using radioimmunoassays (RIAs), which require a large amount of tissue $(\geq 20 \mathrm{mg})$ for 
androgen measurement $[1,2]$. There have been few reports regarding the correlation between prostate cancer aggressiveness and androgen concentrations measured in smaller prostate tissue samples, such as those obtained by needle biopsy.

Advancements in liquid-chromatography tandem mass spectrometry (LC-MS/MS) methods mean that $\mathrm{T}$ and DHT levels can be measured in small tissue samples with high sensitivity and reliability [3-6]. LC-MS/MS can be used to measure androgen concentrations in tissue samples as small as those obtained by a single needle biopsy (approximately $3 \mathrm{mg}$ ), and the latest LC-MS/MS technique is more than 10 times as sensitive as the RIAs used in the past, especially in the lower concentration range [7].

Previous reports revealed that $\mathrm{T}$ levels were higher and DHT levels lower in prostate cancer tissues compared with tissues from patients with benign prostatic hyperplasia, although there is currently no consensus on androgen concentrations in prostate cancer tissues from men with different stages and with different pathological grades of disease [6,8-10]. Moreover, the relationship between tissue androgen concentrations and tumor behavior in prostate cancer is not clear. In the present study, we measured androgen ( $\mathrm{T}$ and DHT) levels in blood and prostate tissues using LC-MS/MS and analyzed the correlations between these levels and prognostic factors in patients with prostate cancer.

\section{Methods}

\section{Patients}

A total of 359 patients with suspected prostate cancer underwent prostate needle biopsy for primary pathological diagnosis at major cancer treatment facilities in Japan between April 2000 and July 2003. Blood samples were also collected. All blood samples were taken between $09.00 \mathrm{~h}$ and $15.00 \mathrm{~h}$ to minimize the effect of daily $\mathrm{T}$ variations. Patients underwent a systematic needle biopsy. An additional needle biopsy sample was taken from the peripheral zone of the prostate as a chemical biopsy, for the simultaneous determination of $\mathrm{T}$ and DHT. The tissues were immediately frozen at $-70^{\circ} \mathrm{C}$. Of the 359 patients, 163 were shown not to have cancer and data for the remaining 196 men diagnosed with prostate cancer were analyzed. The patient characteristics are shown in Table 1.

$\mathrm{T}$ and DHT concentrations in prostate tissues and blood were determined by LC-MS/MS. The method was validated to ensure that the result was within the $20 \%$ range for accuracy and precision [7]. The determination limit of the method was $0.5 \mathrm{pg} /$ shot for $\mathrm{T}$ and $1 \mathrm{pg} / \mathrm{shot}$ for DHT. The concentrations of T and DHT were subsequently expressed in $\mathrm{pg} / \mathrm{mg}$.

We analyzed the relationships between $\mathrm{T}$ and DHT levels in prostate tissue and blood and prognostic factors
Table 1 Patient characteristics

\begin{tabular}{ll}
\hline No. patients & 196 \\
\hline Age, years (mean, SD) & $70.6(7.334)$ \\
PSA, ng/mL (median, 95\% Cl) & $11.5(32.43-82.73)$ \\
Prostate volume, $\mathrm{cm}^{3}$ (median, 95\% Cl) & $27.7(29.83-34.91)$ \\
Gleason score $\leq 7, \geq 8(\%)$ & $130(67.4), 63(32.6)$ \\
Clinical stage $\leq I I I, \geq I V(\%)$ & $166(86.0), 27(14.0)$ \\
$\%$ Positive core $<30 \%, \geq 30 \%(\%)$ & $143(74.1), 50(25.9)$ \\
\hline
\end{tabular}

SD: Standard deviation; PSA: Prostate-specific antigen; Cl: Confidence interval.

including Gleason score, clinical stage, and percentage of positive biopsy cores (\% positive cores) using multivariate analysis. All prostate biopsy samples were reviewed by a central pathologist. Informed consent was obtained from all patients and the experimental procedures were conducted in accord with the ethical standards of the Helsinki Declaration. This study was approved by each of the participating institution's review boards (Additional file 1).

\section{Biological samples}

Each needle chemical biopsy prostate sample (2-8 $\mathrm{mg}$ ) from patients with prostate cancer was placed in a microtube and frozen immediately in liquid nitrogen or in a dry-ice box, and then stored at $-70^{\circ} \mathrm{C}$ until hormone analysis. Serum samples were separated from blood and stored at $-70^{\circ} \mathrm{C}$ until analysis.

\section{Chemicals and materials}

T, DHT, $\left[16,16,17 \alpha-{ }^{2} \mathrm{H}_{3}\right]-\mathrm{T}\left(\mathrm{T}-\mathrm{d}_{3}\right)$, and $\left[16,16,17 \alpha-{ }^{2} \mathrm{H}_{3}\right]-$ DHT $\left(\right.$ DHT- $d_{3}$ ) were purchased from Sigma-Aldrich (St. Louis, MO, USA). The Bond Elut $\mathrm{C}_{18}$ cartridge was purchased from Varian (Palo Alto, CA, USA), and 4dimethylaminopyridine (DAP), 2-methyl-6-nitrobenzoic anhydride (MNBAn), and picolinic acid (PA) were purchased from Tokyo Kasei Industry (Tokyo, Japan). Triethylamine (TEA) was purchased from Wako Pure Chemical Industries (Osaka, Japan). The Cadenza CD C-18 columns and Capcell Pak SCX UG80 pre-columns were purchased from Intact (Kyoto, Japan) and Shiseido (Tokyo, Japan), respectively.

The derivatization reagent was prepared as follows: $10 \mathrm{mg}$ DAP, $20 \mathrm{mg}$ MNBAn, and $25 \mathrm{mg}$ of PA were dissolved in $1 \mathrm{~mL}$ of tetrahydrofuran and the mixture was agitated until it became cloudy or crystals appeared. The reagent solution was used after 3-5 min [5]. Serum prostate-specific antigen (PSA) levels were measured using a DPC Imrise third generation PSA assay kit.

\section{LC-MS/MS}

Serum hormone levels were determined by LC-MS/MS, as described by Yamashita et al. [5]. T and DHT levels in prostate tissue samples were measured using an API5000 triple-stage quadrupole mass spectrometer (Applied 
Biosystems, Foster City, CA, USA) connected to a Shimadzu LC-20 AD pump and Shimadzu SIL HTC autosampler (Shimadzu, Kyoto, Japan) and an electrospray ionization (ESI) ion-source device. The columns used were a Capcell Pak SCX UG80 pre-column $(35 \mathrm{~mm} \times 2 \mathrm{~mm}$ internal diameter, particle size $5 \mu \mathrm{m})$ and a Cadenza $C D-C_{18}$ analytical column $(150 \mathrm{~mm} \times 3 \mathrm{~mm}$ internal diameter, particle size $3 \mu \mathrm{m}$ ), which had been maintained at $40^{\circ} \mathrm{C}$.

The mobile phase consisted of $\mathrm{CH}_{3} \mathrm{CN}-\mathrm{MeOH}$ (50:50, $\mathrm{v} / \mathrm{v}$ ) (solvent A) and $0.1 \%$ formic acid (solvent B). For gradient elution, A/B was used at a ratio of 60/40-90/10 between 0 and $5.0 \mathrm{~min}$, and $90 / 10-100 / 0$ between 5.0 and $7.0 \mathrm{~min}$. Solvent A alone was used between 7.0 and $9.0 \mathrm{~min}$. A/B was used at 100/0-60/40 between 9.0 and $11 \mathrm{~min}$. The flow rate was $0.4 \mathrm{~mL} / \mathrm{min}$. The following ESI conditions were used: spray voltage, 3,300 V; collision gas, nitrogen, 45 psi; curtain gas, 11 psi; ion source temperature, $600^{\circ} \mathrm{C}$; and ion polarity, positive.

\section{Tissue hormone analysis}

Each frozen prostate tissue sample (1-3 mg, 5-13 mm) was weighed and then a piece of the sample was cut off with scissors. Purified water $(0.5 \mathrm{~mL})$ was added to the cut sample, which was then homogenized for $20 \mathrm{~s}$ using an Ultra-Turrax homogenizer with an ice-cooling bath, and then washed with $0.5 \mathrm{~mL}$ water. Ethanol $(3 \mathrm{~mL})$ and $100 \mathrm{pg}$ of $\mathrm{T}-\mathrm{d}_{3}$ and DHT- $\mathrm{d}_{3}$ were added to the homogenate and the mixture was shaken at $50^{\circ} \mathrm{C}$ for $2 \mathrm{~h}$. The solution was allowed to stand at $4^{\circ} \mathrm{C}$ overnight to allow complete precipitation of the protein. After centrifugation $\left(4^{\circ} \mathrm{C}, 3,000 \mathrm{rpm}, 10 \mathrm{~min}\right)$, the supernatant was isolated and the solvent was evaporated using a centrifugation evaporator. The residue was dissolved in methanol $(0.25 \mathrm{~mL})$, diluted with purified water $(1 \mathrm{~mL})$, and loaded onto a Bond Elut $\mathrm{C}_{18}$ cartridge pre-conditioned with methanol $(6 \mathrm{~mL})$ and purified water $(6 \mathrm{~mL})$. The cartridge was washed with purified water $(1 \mathrm{~mL})$ followed by $30 \%$ acetonitrile solution (v/v, $3 \mathrm{~mL})$. T and DHT were subsequently eluted with $70 \%$ acetonitrile solution (v/v, $3 \mathrm{~mL}$ ) and the solvent was removed using a centrifugation evaporator.

The residue was dissolved in $100 \mu \mathrm{L}$ reagent mixture, prepared as described above. TEA $(20 \mu \mathrm{L})$ was added and the resulting mixture was allowed to stand at room temperature for $30 \mathrm{~min}$. After dilution of the reaction mixture with $1 \%$ acetic acid solution (v/v, $1 \mathrm{~mL}$ ) to stop the reaction, the resulting derivative was loaded onto a Bond Elut $\mathrm{C}_{18}$ cartridge pre-conditioned with methanol and purified water. The cartridge was washed with purified water $(1 \mathrm{~mL})$ followed by $40 \%$ acetonitrile solution $(\mathrm{v} / \mathrm{v}, 3 \mathrm{~mL})$. The derivatives were then eluted with $80 \%$ acetonitrile solution (v/v, $3 \mathrm{~mL})$. The solvent was evaporated to dryness using a centrifugation evaporator at $53-55^{\circ} \mathrm{C}$, the residue was dissolved in $40 \%$ acetonitrile solution (v/v, $100 \mu \mathrm{L})$, and a $40-\mu \mathrm{L}$ aliquot of the solution was subjected to LC-ESI-MS/MS.

\section{Validation of analytical methods}

The inter- and intra-assay accuracies and precisions of the LC-MS/MS were tested as described by Shibata et al. [11].

\section{Cancerous and noncancerous regions in the prostate}

Hormone-naïve prostate cancer specimens were obtained from 10 patients by radical prostatectomy. Each prostate specimen was cut into two mirror-image 2.5-mm-thick fragments, each of which was cut into a further 90 sections. All 90 sections were used for the androgen assays and histopathology diagnosis, to analyze the relationships between tissue androgen concentrations with histopathological findings. There was no significant difference in tissue T or DHT levels between cancerous and noncancerous sections of individual prostate cancer sections (mean T levels, $\mathrm{p}=0.796$; mean DHT levels, $\mathrm{p}=0.912$ ). The tissues used for androgen concentration measurements in this study were not examined by a pathologist, because the whole of the samples were used for androgen measurement. Cancer diagnosis was based on other, simultaneously-obtained biopsy specimens. These results indicated that the results of androgen measurements were unaffected by the use of cancerous or noncancerous lesions.

\section{Histopathology}

All prostate biopsy samples were reviewed by a central pathologist. Pathological grading was performed according to the Gleason classification system. Histological diagnoses were made by the central pathologist blinded to the patients' serum and prostate androgen measurements.

\section{Statistical analysis}

We compared tissue and blood androgen levels using Pearson's correlation coefficient. If some factors were found to be correlated with other factors, the correlated factors were not analyzed simultaneously because of multicollinearity. We also analyzed the relationships between $\mathrm{T}$ and DHT levels in tissue and blood and prognostic factors including Gleason score, clinical stage, and \% positive cores by multivariate analyses using a logistic regression model. All data were analyzed using IBM SPSS ver. 21 software. Each test was two-sided, and p values $<0.05$ were considered significant.

\section{Results}

Androgen levels in blood and prostate tissue obtained by needle biopsy

The androgen levels in prostate tissue and peripheral blood are shown in Table 2. serum $\mathrm{T}$ levels were almost 10-fold higher than DHT levels in peripheral blood, 
Table 2 Androgen levels in blood and prostate tissue of patients with prostate cancer $(n=196)$

\begin{tabular}{ll}
\hline T (blood), pg/mL (median, 95\% Cl) & 3551.0 (3499.8-3902.2) \\
DHT (blood), pg/mL (median, 95\% Cl) & 330.5 (333.2-382.3) \\
T (tissue), pg/mg (median, 95\% Cl) & $0.5667(0.9401-1.3820)$ \\
DHT (tissue), pg/mg (median, 95\% Cl) & 7.0625 (8.7513-11.6266)
\end{tabular}

$T$ : Testosterone; Cl: Confidence interval; DHT: Dihydrotestosterone.

whereas DHT levels in prostate tissue were almost 10fold higher than tissue $\mathrm{T}$ levels. These serum and tissue androgen levels were similar to those in other reports concerning prostate cancer patients.

Correlations between $\mathrm{T}$ and DHT levels in serum and prostate tissue are shown in Table 3. There were strong correlations between $\mathrm{T}$ and DHT blood levels (Pearson correlation coefficient: 0.76996$)$ and we therefore did not analyze these two factors simultaneously, because of multicollinearity.

\section{Gleason score}

The relationships between Gleason score and androgen levels and other clinical factors are shown in Table 4. Logistic regression identified high serum PSA (hazard ratio [HR]: 1.022, $\mathrm{p}=0.001$ ), low blood T levels (HR: 0.706, $\mathrm{p}=0.012$ ) and high tissue $\mathrm{T}$ levels (HR: 1.388, $\mathrm{p}=0.041$ ) as factors significantly associated with high Gleason score.

\section{Clinical stage}

High serum PSA levels (HR: 1.009, $\mathrm{p}=0.010)$ and high tissue $\mathrm{T}$ levels (HR: 1.713, $\mathrm{p}=0.002$ ) were significantly related to advanced clinical stage (Table 4).

\section{$\%$ Cancer-positive cores}

High serum PSA (HR: 1.017, $\mathrm{p}=0.005$ ), low tissue DHT (HR: 0.878, $\mathrm{p}=0.003$ ) and high tissue $\mathrm{T}$ levels (HR: 2.432, $\mathrm{p}=0.001$ ) were significantly related to a high $\%$ positive cores (Table 4).

In summary, multivariate analysis demonstrated that high serum PSA and high tissue T levels were significantly associated with poor-prognosis factors such as high Gleason score, advanced clinical stage, and high \% positive cores in men with prostate cancer.

Table 3 Correlations between testosterone and dihydrotestosterone in serum and prostate tissue*

\begin{tabular}{lllll}
\hline & T (blood) & T (tissue) & DHT (blood) & DHT (tissue) \\
\hline T (blood) & 1 & 0.00901 & 0.76996 & 0.08784 \\
T (tissue) & 0.00901 & 1 & 0.02471 & 0.25907 \\
DHT (blood) & 0.76996 & 0.02471 & 1 & 0.16242 \\
DHT (tissue) & 0.08784 & 0.25907 & 0.16242 & 1 \\
\hline
\end{tabular}

*Pearson correlation coefficients.

\section{Discussion}

The current study demonstrated associations between high serum PSA and high tissue $\mathrm{T}$ levels and poorprognosis factors, including high Gleason score, advanced clinical stage and high \% positive cores, in men with prostate cancer. To ensure that histological examination and androgen measurement were conducted simultaneously, we measured androgen levels in 90 tissue samples from 10 prostatectomy specimens. Each specimen was cut into two 2.5-mm-thick mirror-image fragments for androgen assay and histopathological diagnosis, respectively, allowing direct analysis of the relationship between androgen levels and histopathological findings. Further, we found no difference in tissue $\mathrm{T}$ levels between cancerous and noncancerous sections of individual prostate cancer specimens. This indicates that not only prostate cancer cells themselves but also their surrounding cells might be responsible for the androgen biosynthesis environment in prostate cancer tissues. In this study, we measured androgen levels in single needle prostate cancer biopsies, but did not confirm if the specimen used for androgen measurement was cancerous or noncancerous. However, the above results suggest that the results of the androgen assay would not be influenced by the presence or absence of cancerous tissue in the sample.

Several studies of androgen concentrations in prostate tissues have used bulk tissues such as prostatectomy specimens, and androgen levels have been measured by RIA methods $[3,4,9,12-14]$. However, the present study demonstrated that: (1) these measurements could be conducted using the small amounts of tissue obtained by needle biopsy, rather than excised prostate tissues; and (2) androgen measurements could be carried out much more precisely than by RIA, by using LC-MS/MS. Nishiyama and colleagues used LC-MS/MS and reported that 47 patients with prostate cancer with Gleason scores of 7-10 had low DHT levels in the prostate, as shown by univariate analysis [9]. In the current study, we found that low tissue DHT levels were associated with a high $\%$ positive cores.

Previous studies of tissue androgen measurements have had several problems, including small sample sizes, tissue-handling issues [15], problems with methodological accuracy and concerns about confounding factors. The tissue content of DHT decreases rapidly within $2 \mathrm{~h}$ at $37^{\circ} \mathrm{C}$, and the tissue samples used in the present study were therefore frozen immediately $\left(\right.$ at $-70^{\circ} \mathrm{C}$ ) until analysis. To ensure the quality and precision of our measurement methods, we used prostate tissues spiked with various amounts of $\mathrm{T}$ or DHT to determine the precision of the LC/MS-MS method, and performed multivariate analysis after controlling for confounding factors.

Our results confirmed that high $\mathrm{T}$ levels in prostate tissue are related to high Gleason score, advanced clinical stage 
Table 4 Correlation between prognostic factors and androgen concentrations in blood and prostate tissue*

\begin{tabular}{|c|c|c|c|c|c|c|c|c|c|c|c|c|c|c|c|}
\hline \multirow[b]{2}{*}{ Parameter } & \multicolumn{5}{|c|}{ Gleason score } & \multicolumn{5}{|l|}{ Clinical stage } & \multicolumn{5}{|c|}{$\%$ positive cores } \\
\hline & $\geq 8$ & $\leq 7$ & $\mathrm{p}$ value & HR & $95 \% \mathrm{Cl}$ & $\geq \mathrm{IV}$ & sIII & $\mathrm{p}$ value & $\mathrm{HR}$ & $95 \% \mathrm{Cl}$ & $\geq 30 \%$ & $<30 \%$ & $p$ value & HR & $95 \% \mathrm{Cl}$ \\
\hline No. of patients & 63 & 130 & & & & 27 & 166 & & & & 50 & 143 & & & \\
\hline Median age (SD), years & $73.0(7.1)$ & $69.5(7.2)$ & 0.076 & 1.050 & $0.995-1.108$ & $75.0(7.3)$ & $70.0(7.2)$ & 0.255 & 1.049 & $0.966-1.138$ & $73.0(7.4)$ & $70.0(7.1)$ & 0.120 & 1.052 & $0.987-1.121$ \\
\hline $\begin{array}{l}\text { Median serum PSA } \\
(95 \% \mathrm{Cl}), \mathrm{ng} / \mathrm{mL}\end{array}$ & $\begin{array}{l}32.1 \\
(69.2-216.2)\end{array}$ & $\begin{array}{l}8.76 \\
(12.3-20.2)\end{array}$ & 0.001 & 1.022 & $1.009-1.036$ & $\begin{array}{l}55.9 \\
(113.4-435.8)\end{array}$ & $\begin{array}{l}9.68 \\
(16.5-27.9)\end{array}$ & 0.010 & 1.009 & $1.002-1.017$ & $\begin{array}{l}52.8 \\
(83.6-262.0)\end{array}$ & $\begin{array}{l}8.61 \\
(9.6-24.8)\end{array}$ & 0.005 & 1.017 & $1.005-1.030$ \\
\hline $\begin{array}{l}\text { Median prostate } \\
\text { volume, } \mathrm{mL}\end{array}$ & $\begin{array}{l}27.0 \\
(28.5-40.0)\end{array}$ & $\begin{array}{l}27.9 \\
(28.8-34.0)\end{array}$ & 0.387 & 0.991 & $0.970-1.012$ & $\begin{array}{l}33.2 \\
(31.7-55.1)\end{array}$ & $\begin{array}{l}27.5 \\
(28.3-32.8)\end{array}$ & 0.057 & 1.024 & $0.999-1.049$ & $\begin{array}{l}28.4 \\
(29.3-41.0)\end{array}$ & $\begin{array}{l}27.6 \\
(28.6-34.1)\end{array}$ & 0.164 & 0.982 & $0.957-1.007$ \\
\hline $\begin{array}{l}\text { Median concentration } \\
\text { of T }(95 \% \mathrm{Cl} \text { ) (blood) } \\
\text { (/1000), pg/mL }\end{array}$ & $\begin{array}{l}3.11 \\
(2.90-3.62)\end{array}$ & $\begin{array}{l}3.64 \\
(3.67-4.14)\end{array}$ & 0.012 & 0.706 & $0.538-0.926$ & $\begin{array}{l}3.21 \\
(2.56-4.06)\end{array}$ & $\begin{array}{l}3.61 \\
(3.56-3.96)\end{array}$ & 0.354 & 0.839 & $0.579-1.216$ & $\begin{array}{l}3.12 \\
(2.84-3.74)\end{array}$ & $\begin{array}{l}3.66 \\
(3.62-4.06)\end{array}$ & 0.113 & 0.78 & $0.575-1.060$ \\
\hline $\begin{array}{l}\text { Median concentration } \\
\text { of DHT ( } 95 \% \mathrm{Cl}) \\
\text { (tissue), } \mathrm{pg} / \mathrm{mg}\end{array}$ & $\begin{array}{l}5.31 \\
(6.15-10.27)\end{array}$ & $\begin{array}{l}7.31 \\
(9.26-13.02)\end{array}$ & 0.222 & 0.974 & $0.935-1.016$ & $\begin{array}{l}4.68 \\
(3.94-11.16)\end{array}$ & $\begin{array}{l}7.28 \\
(9.04-12.18)\end{array}$ & 0.756 & 0.992 & $0.942-1.044$ & $\begin{array}{l}5.26 \\
(4.86-7.32)\end{array}$ & $\begin{array}{l}7.58 \\
(9.77-13.46)\end{array}$ & 0.003 & 0.878 & $0.806-0.956$ \\
\hline $\begin{array}{l}\text { Median concentration } \\
\text { of T ( } 95 \% \text { Cl) (tissue), } \\
\text { pg/mg }\end{array}$ & $\begin{array}{l}0.90 \\
(1.20-2.23)\end{array}$ & $\begin{array}{l}0.46 \\
(0.68-1.09)\end{array}$ & 0.041 & 1.388 & $1.013-1.900$ & $\begin{array}{l}2.03 \\
(1.74-3.84)\end{array}$ & $0.50(0.72-1.06)$ & 0.002 & 1.713 & $1.227-2.391$ & $\begin{array}{l}1.03 \\
(1.42-2.70)\end{array}$ & $0.47(0.67-1.02)$ & 0.001 & 2.432 & $1.425-4.148$ \\
\hline
\end{tabular}

*Multivariate analysis by logistic regression. SD: Standard deviation; HR: Hazard ratio; Cl: Confidence interval. 
and a high \% positive cores. Low DHT levels in prostate tissue were also associated with a high \% positive cores. Thomas et al. reported that prostate-tissue expression levels of 5alpha-reductase type 1 and type 2 were increased in high-grade, compared with low-grade prostate cancer, which might explain the relationships between high $\mathrm{T}$ and low DHT prostate tissue levels and poor prognostic factors [16]. de Winter et al. reported that the intensity of androgen receptor immunostaining was decreased in more aggressive tumors [17], suggesting that androgen receptor heterogeneity might also offer an explanation of our findings.

Based on our results, we propose that prostate tissue $\mathrm{T}$ level measured by chemical biopsy may be a useful prognostic factor, in addition to Gleason score, clinical stage and \% positive biopsy cores, for aiding the design of suitable therapeutic programs for prostate cancer. It is important that the tissue $\mathrm{T}$ level as a prognostic marker is determined simultaneously with the biopsy, to allow identification of the individual patient's prognostic factors before making decisions about treatment options. Moreover, tissue $\mathrm{T}$ could help to subclassify Gleason 7 needle biopsies into a high-T and normal-T group, to distinguish between those patients with more aggressive disease and those with more indolent disease. This would be useful for selecting suitable patients for active surveillance.

Our results revealed that low serum $\mathrm{T}$ was associated with a Gleason score $\geq 8$. In this regard, Garcia-Cruz et al. reported that low $\mathrm{T}$ was associated with high D'Amico classification, by multivariate analysis [18]. Hoffman et al. also reported that low free $\mathrm{T}$ indicated an increased risk of a biopsy Gleason score $\geq 8(11 \%$ vs $0 \%, \mathrm{p}=0.025)$. Our results are compatible with the hypothesis that low serum androgen levels may influence poor-prognosis factors in prostate cancer [19], but no mechanism for this relationship has yet been established.

In our previous study, we first reported that CRPC may be predicted by prostate tissue T and DHT levels in a single biopsy specimen, obtained as a chemical biopsy, in patients undergoing cancer checkups, whether for prostate cancer or not [11]. Our present finding that high tissue $\mathrm{T}$ levels might be associated with poor prognostic factors may thus help predict prostate cancer aggressiveness.

The correlation of high tissue $\mathrm{T}$ levels with poor prognostic parameters (Gleason score, advanced clinical stage, high \% positive cores) detected in this study suggests that tissue $\mathrm{T}$ may have a prognostic role, though no prognostic information was available in the current study. Further studies with larger numbers of patients and longer followup are warranted to confirm the validity of high tissue $\mathrm{T}$ levels as a prognostic marker.

\section{Conclusions}

We conclude that high serum PSA levels and high tissue $\mathrm{T}$ levels in men with prostate cancer are significantly associated with indicators of poor prognosis, including advanced clinical stage, high Gleason score and \% positive cores. Tissues $\mathrm{T}$ levels determined from biopsy specimens, in combination with pathological features, may be one of several useful diagnostic tools for predicting the prognosis and determining a suitable therapeutic program for patients with prostate cancer.

\section{Additional file}

Additional file 1: Ethics committee.

\section{Abbreviations}

LC-MS/MS: Liquid-chromatography tandem mass spectrometry; T: Testosterone; DHT: Dihydrotestosterone; PSA: Prostate-specific antigen; CRPC: Castration-resistant prostate cancer; RIA: Radioimmunoassay.

\section{Competing interests}

The authors declare that they have no competing interests.

\section{Authors' contributions}

YK and KZ designed the study. YM contributed to statistical analysis and wrote the manuscript. SM and KS supported the statistical analysis. HU, SU, YS, NM, TI, AM, YS, NN and HS contributed to collecting the tissue samples and clinical data. SH contributed to measurement of androgen concentrations. $\mathrm{MH}$ contributed to pathological examination. All authors have read and approved the final manuscript.

\section{Acknowledgments}

This work was supported by a Grant-in-Aid for Scientific Research from the Japan Science and Technology Agency. We thank Emeritus Professor Akihiko Okuyama and Dr. Masashi Nakayama (University of Osaka) and Emeritus Professor Hiroshi Kanetake (University of Nagasaki) for their valuable contributions to this research; Prof. K. Ito (Gunma University) for helpful advice on the statistical analysis; Mr. Y. Miyashiro (ASKA Pharma) for his contribution to androgen measurement; and Prof. K. Noguchi (Yokohama City University Medical Center), Dr. K. Ishii (Mie University), Dr. S. Noguchi (Yokosuka Kyosai Hospital), Dr. T. Murai (International Goodwill Hospital) and Dr. I. Ikeda (Yokohama Minami Kyosai Hospital) for gathering cases.

\section{Author details}

'Department of Urology, Yokohama City University Graduate School of Medicine Yokohama, Japan. ${ }^{2}$ Department of Biostatistics and Epidemiology, Graduate School of Medicine, Yokohama City University, Yokohama, Japan. ${ }^{3}$ Department of Urology, Gunma University Graduate School of Medicine, Maebashi, Japan. ${ }^{4}$ Department of Urologic Surgery and Andrology, Sapporo Medical University School of Medicine, Sapporo, Japan. ${ }^{5}$ Department of Urology, Chiba University Graduate School of Medicine, Chiba, Japan. ${ }^{6}$ Department of Integrative Cancer Therapy and Urology, Kanazawa University Graduate School of Medical Science, Kanazawa, Japan. ${ }^{7}$ Department of Nephro-Urologic Surgery and Andrology, Mie University Graduate School of Medicine, Tsu, Japan. ${ }^{8}$ Department of Urology, Osaka University Graduate School of Medicine, Osaka, Japan. ${ }^{9}$ Department of Nephro-urology, Nagasaki University Graduate School of Biomedical Sciences, Nagasaki, Japan. ${ }^{10}$ ASKA Pharma Medical Co., Ltd, Kawasaki, Japan. ${ }^{11}$ Department of Urology and Pathology, Kanagawa Cancer Center, Asahi-ku, Yokohama, Japan.

Received: 31 May 2014 Accepted: 24 September 2014

Published: 26 September 2014

\section{References}

1. Belanger B, Belanger A, Labrie F, Dupont A, Cusan L, Monfette G: Comparison of residual C-19 steroids in plasma and prostatic tissue of human, rat and guinea pig after castration: unique importance of extratesticular androgens in men. J Steroid Biochem 1989, 32(5):695-698.

2. Mohler JL, Gregory CW, Ford OH 3rd, Kim D, Weaver CM, Petrusz P, Wilson EM, French FS: The androgen axis in recurrent prostate cancer. Clin Cancer Res 2004, 10(2):440-448. 
3. Montgomery RB, Mostaghel EA, Vessella R, Hess DL, Kalhorn TF, Higano CS, True LD, Nelson PS: Maintenance of intratumoral androgens in metastatic prostate cancer: a mechanism for castration-resistant tumor growth. Cancer Res 2008, 68(11):4447-4454.

4. Titus MA, Schell MJ, Lih FB, Tomer KB, Mohler JL: Testosterone and dihydrotestosterone tissue levels in recurrent prostate cancer. Clin Cancer Res 2005, 11(13):4653-4657.

5. Yamashita K, Miyashiro Y, Maekubo H, Okuyama M, Honma S, Takahashi M, Numazawa M: Development of highly sensitive quantification method for testosterone and dihydrotestosterone in human serum and prostate tissue by liquid chromatography-electrospray ionization tandem mass spectrometry. Steroids 2009, 74(12):920-926.

6. Mizokami A, Koh E, Fujita H, Maeda Y, Egawa M, Koshida K, Honma S, Keller $E T$, Namiki M: The adrenal androgen androstenediol is present in prostate cancer tissue after androgen deprivation therapy and activates mutated androgen receptor. Cancer Res 2004, 64(2):765-771.

7. Matsui F, Koh E, Yamamoto K, Sugimoto K, Sin HS, Maeda Y, Honma S, Namiki M: Liquid chromatography-tandem mass spectrometry (LC-MS/ MS) assay for simultaneous measurement of salivary testosterone and cortisol in healthy men for utilization in the diagnosis of late-onset hypogonadism in males. Endocr J 2009, 56(9):1083-1093.

8. Ghanadian R, Puah CM: Relationships between oestradiol-17 beta, testosterone, dihydrotestosterone and 5 alpha-androstane- 3 alpha, 27 beta-diol in human benign hypertrophy and carcinoma of the prostate. J Endocrinol 1981, 88(2):255-262.

9. Nishiyama T, Ikarashi T, Hashimoto Y, Suzuki K, Takahashi K: Association between the dihydrotestosterone level in the prostate and prostate cancer aggressiveness using the Gleason score. J Urol 2006, 176(4 Pt 1):1387-1391.

10. Nishiyama T, Ikarashi T, Hashimoto Y, Wako K, Takahashi $K$ : The change in the dihydrotestosterone level in the prostate before and after androgen deprivation therapy in connection with prostate cancer aggressiveness using the Gleason score. J Urol 2007, 178(4 Pt 1):1282-1288. discussion 1288-1289.

11. Shibata Y, Suzuki K, Arai S, Miyoshi Y, Umemoto S, Masumori N, Kamiya N, Ichikawa T, Kitagawa Y, Mizokami A, Sugimura Y, Nonomura N, Sakai H, Honma S, Kubota Y: Impact of pre-treatment prostate tissue androgen content on the prediction of castration-resistant prostate cancer development in patients treated with primary androgen deprivation therapy. Androl 2013, 1(3):505-511.

12. Vermeulen A, Giagulli VA, De Schepper P, Buntinx A, Stoner E: Hormonal effects of an orally active 4-azasteroid inhibitor of 5 alpha-reductase in humans. Prostate 1989, 14(1):45-53.

13. Geller J, Albert J, Lopez D, Geller S, Niwayama G: Comparison of androgen metabolites in benign prostatic hypertrophy (BPH) and normal prostate. J Clin Endocrinol Metab 1976, 43(3):686-688.

14. Gustafsson O, Norming U, Gustafsson S, Eneroth P, Astrom G, Nyman CR: Dihydrotestosterone and testosterone levels in men screened for prostate cancer: a study of a randomized population. Br J Urol 1996, 77(3):433-440.

15. Walsh PC, Hutchins GM, Ewing LL: Tissue content of dihydrotestosterone in human prostatic hyperplasis is not supranormal. J Clin Invest 1983, 72(5):1772-1777.

16. Thomas LN, Douglas RC, Lazier CB, Gupta R, Norman RW, Murphy PR, Rittmaster RS, Too CK: Levels of 5alpha-reductase type 1 and type 2 are increased in localized high grade compared to low grade prostate cancer. J Urol 2008, 179(1):147-151

17. de Winter JA, Trapman J, Brinkmann AO, Boersma WJ, Mulder E, Schroeder FH, Claassen $E$, van der Kwast TH: Androgen receptor heterogeneity in human prostatic carcinomas visualized by immunohistochemistry. J Pathol 1990, 160(4):329-332.

18. Garcia-Cruz E, Piqueras M, Huquet J, Peri L, Izquierdo L, Musquera M, Franco A, Alvarez-Vijande R, Ribal MJ, Alcaraz A: Low testosterone levels are related to poor prognosis factors in men with prostate cancer prior to treatment. BJU Int 2012, 110(11 Pt B):E541-E546.

19. Morgentaler A: Testosterone and prostate cancer: an historical perspective on a modern myth. Eur Urol 2006, 50(5):935-939.

doi:10.1186/1471-2407-14-717

Cite this article as: Miyoshi et al: High testosterone levels in prostate tissue obtained by needle biopsy correlate with poor-prognosis factors in prostate cancer patients. BMC Cancer 2014 14:717.

\section{Submit your next manuscript to BioMed Central and take full advantage of:}

- Convenient online submission

- Thorough peer review

- No space constraints or color figure charges

- Immediate publication on acceptance

- Inclusion in PubMed, CAS, Scopus and Google Scholar

- Research which is freely available for redistribution 